\title{
Alteration of $\mathrm{H}_{2}$ receptor sensitivity in duodenal ulcer patients after maintenance treatment with an $\mathrm{H}_{2}$ receptor antagonist
}

\author{
D B JONES, C W HOWDEN, D W BURGET, CINDY SILLETTI, AND \\ R H HUNT \\ From the Division of Gastroenterology, McMaster University Medical Centre, Hamilton, Ontario, Canada
}

SUMmaRY The effects of a specific $\mathrm{H}_{2}$ receptor agonist impromidine, on gastric acid secretion were measured in six patients with duodenal ulcer in clinical remission before and after three months treatment with ranitidine $150 \mathrm{mg}$ nocte. After treatment basal acid output increased from $1 \cdot 2$ to $2 \cdot 8$ $\mathrm{mmol} / \mathrm{h}$ and after maximal impromidine stimulation from $36 \cdot 9(4 \cdot 7)$ to $44 \cdot 2(6 \cdot 2) \mathrm{mmol} / \mathrm{h}(\mathrm{p}<0 \cdot 02)$. Intravenous ranitidine $50 \mathrm{mg}$ was given at the end of the impromidine infusion on each study day; the antisecretory effect of intravenous ranitidine was accentuated after the treatment with ranitidine from a trough acid output of $8 \cdot 5(1 \cdot 2) \mathrm{mmol} / \mathrm{h}$ before, to $3 \cdot 8(1 \cdot 5) \mathrm{mmol} / \mathrm{h}(\mathrm{p}<0.05)$ after, treatment. The increased response to the $\mathrm{H}_{2}$ agonist impromidine and the $\mathrm{H}_{2}$ antagonist ranitidine after treatment with ranitidine suggests an enhanced sensitivity of the $\mathrm{H}_{2}$ receptor. This might be explained on the basis of an increase in the number of $\mathrm{H}_{2}$ receptors ('up-regulation').

The discovery of the histamine $\mathrm{H}_{2}$ receptor on the parietal cell' initiated the development of $\mathrm{H}_{2}$ receptor antagonists with potent gastric antisecretory activity and these agents have now become firmly established in the treatment of peptic ulceration. ${ }^{2}$ After heaing of duodenal ulcer by the $\mathrm{H}_{2}$ receptor antagonists, cimetidine and ranitidine, maintenance treatment with either of these drugs has successfully reduced ulcer relapse rates at 12 months from approximately $80 \%$ without therapy to about $30 \%$ on continuous maintenance treatment. ${ }^{3}$ There has been some suggestion that the antisecretory effects of $\mathrm{H}_{2}$ receptor antagonists may alter with continuous $\mathrm{H}_{2}$ receptor blockade during prolonged treatment. Previous studies have utilised either pentagastrin or peptone meals as secretagogues in tests of gastric acid secretion. ${ }^{-6}$ Because the inter-relationship between histamine, muscarinic and gastrin receptors is complex ${ }^{7}$ neither pentagastrin nor a peptone meal specifically identifies a potential alteration in $\mathrm{H}_{2}$ receptor sensitivity after maintenance treatment with a competitive antagonist. Impromidine, however, is

Address for correspondence: Prof Richard H Hunt, FRCP, FRCPC. McMaster University Medical Centre, 1200 Main St West, Hamilton. Ontario L8N 3Z5. Canada.

Received for publication 12 February 1988 a highly potent, and specific agonist for the $\mathrm{H}_{2}$ receptor ${ }^{8}$ exhibiting up to 27 times the affinity of histamine. ${ }^{4}$ In this study we have examined the effect of three months of treatment with ranitidine $150 \mathrm{mg}$ nocte on impromidine stimulated gastric acid secretion in six patients with duodenal ulcer in remission.

\section{Methods}

PATIENTS

Six male patients, aged 33 to 62 years, participated in the study. All had endoscopically confirmed duodenal ulcer previously healed on conventional doses of $\mathrm{H}_{2}$ receptor antagonists before entry in the study. All the patients were non-smokers and none took alcohol to excess. None of the patients had concurrent disease or was taking any other medication. The study was approved ethically by the Research Advisory Committee of the Chedoke-McMaster Hospitals and written, informed consent was obtained from all participants.

STUDY DESIGN

Patients were pretreated with ranitidine $150 \mathrm{mg}$ nocte for three days before the first study day. The first impromidine stimulated gastric secretion study 
was carried out 10 hours after the last dose of ranitidine. On each study day at 0900 hours, after an overnight fast, a 14 French Salem Sump tube (Sherwood Medical Industries, St Louis, MO, USA) was placed in the most dependent part of the stomach, and its position checked by the water recovery test. Gastric juice was collected by continuous aspiration divided into 10 minute intervals throughout the study. After a one hour basal period, an impromidine (Smith, Kline and French Research Ltd, Welwyn, Herts, UK) step dose intravenous infusion was started at a dose of $2.5 \mu \mathrm{g} / \mathrm{kg} / \mathrm{h}$ for 90 minutes. After 90 minutes, the infusion rate was doubled to $5.0 \mu \mathrm{g} / \mathrm{kg} / \mathrm{h}$ for a further 90 minutes, and then doubled again to $10 \mu \mathrm{g} / \mathrm{kg} / \mathrm{h}$ for 210 minutes. At the end of 90 minutes of impromidine $10 \mu \mathrm{g} / \mathrm{kg} / \mathrm{h}$, ranitidine $50 \mathrm{mg}$ was administered intravenously over five minutes and gastric secretion continuously aspirated for the next 120 minutes during continued high dose impromidine infusion.

The volume of each sample was measured, and acid concentration determined by automatic titration (Radiometer, Copenhagen) to $\mathrm{pH} 7 \cdot 00$ with $0.1 \mathrm{M}$ $\mathrm{NaOH}$. Acid output was calculated as the product of volume and concentration.

After the impromidine study, all six patients were continued on three months treatment with ranitidine $150 \mathrm{mg}$ nocte. Within one week of completion of the three months course, the impromidine study was repeated in an identical fashion and started 10 hours after the last dose of ranitidine. This approach generated data for each patient before and at the end of a three month course of ranitidine $150 \mathrm{mg} / \mathrm{h}$.

DATA PRESENTATION

Basal acid output (BAO) was calculated by summation of the acid outputs over the one hour before impromidine infusion and expressed as $\mathrm{mmol} / \mathrm{h}$. Plateau acid outputs during impromidine infusion (PIAO) was calculated by summation of the last six 10 minute aliquots of each 90 minute infusion period, and the results expressed as $\mathrm{mmol} / \mathrm{h}$. In order to estimate the maximal effect of ranitidine on impromidine stimulated acid output, acid output measured between 60 and 90 minutes after bolus ranitidine (representing trough acid output) were summated, and expressed as $\mathrm{mmol} / \mathrm{h}$.

Table Preand post ranitidine treatment impromidine dose response infusion results for acid output expressed in $\mathrm{mmol} / \mathrm{h}$

\begin{tabular}{llllll}
\hline & Basal & Imp 2.5 & Imp 5.0 & Imp 10 & Ran 50 mg \\
\hline Pre & $1.91(0.38)$ & $7 \cdot 15(2 \cdot 8())$ & $21.32(5.39)$ & $36.90(4 \cdot 7)$ & $8.54(1.22)$ \\
Post & $2.79(0.89)$ & $22.49(6 \cdot 16)$ & $35.31(6.38)$ & $44 \cdot 17(6.2)$ & $3.75(1.55)$ \\
p & 0.25 & 0.04 & 0.05 & 0.02 & 0.05 \\
\hline
\end{tabular}

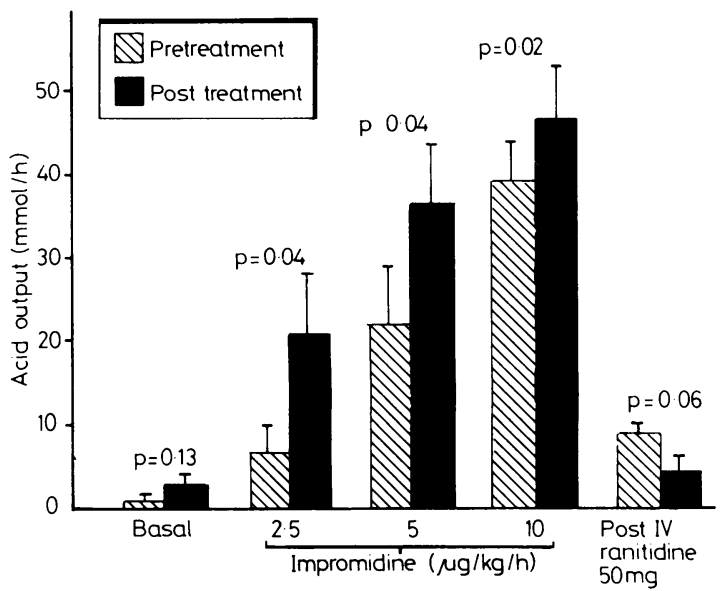

Figure Gastric acid secretion, before and after three months maintenance ranitidine $150 \mathrm{mg}$ treatment, expressed as acid output ( $\mathrm{mmol} / \mathrm{h})$, in basal state (BAO), after three infusion rates of impromidine, and after bolus intravenous ranitidine $50 \mathrm{mg}$.

STATISTICAL ANALYSIS

Data are presented as the mean (SE). Statistical comparisons were made by paired, two tailed, Student's $t$ test, "1" accepting a p value of 0.05 as the minimal level of significance.

\section{Results}

Before and after maintenance ranitidine $150 \mathrm{mg}$ nocte, impromidine resulted in a dose dependent stimulation of gastric acid secretion (Table, Figure) to a maximal acid output of approximately $40 \mathrm{mmol} / \mathrm{h}$ during the highest dose. Apart from transient facial flushing, the impromidine infusion was well tolerated with no serious adverse effects. The intravenous bolus of ranitidine $50 \mathrm{mg}$ resulted in a prompt and dramatic decrease in gastric acid output during the continued high dose impromidine infusion (Table, Figure).

Three months of treatment with ranitidine $150 \mathrm{mg}$ nocte resulted in a non-significant increase in basal acid output from $1.2(0.4)$ to $2.8(0.9) \mathrm{mmol} / \mathrm{h}$ $(p=0 \cdot 25)$. At each of the three stepwise doses of impromidine, three months ranitidine treatment resulted in a significant $(p<0 \cdot 05)$ increase in impromidine stimulated gastric acid secretion compared with pretreatment values (Table). At the highest dose of impromidine infusion, gastric acid output increased from $36.9(4.8) \mathrm{mmol} / \mathrm{h}$ before ranitidine $150 \mathrm{mg}$ treatment to $44.2(6 \cdot 2)$ after $(\mathrm{p}<0 \cdot 02)$.

Similarly, ranitidine treatment resulted in an accentuated response to the intravenous bolus of 
ranitidine $50 \mathrm{mg}$ (Figure). The pretreatment trough acid output before maintenance treatment was 8.5 $(1.2) \mathrm{mmol} / \mathrm{h}$, and was reduced to $3.8(1.6) \mathrm{mmol} / \mathrm{h}$ $(\mathrm{p}<0.05)$ after maintenance treatment (Table)

\section{Discussion}

A variety of stimuli result in increased gastric acid secretion, including histamine, cholinergic and gastrin stimulation. As a working hypothesis, it is postulated $^{\prime 12}$ that the parietal cell has distinct receptors for histamine, acetylcholine, and gastrin and that these receptors interact with, and may potentiate each other. Thus, for example, pentagastrin stimulated acid secretion may be blocked by $\mathrm{H}_{2}$ receptor antagonists. This interaction makes study of the $\mathrm{H}_{2}$ receptor difficult in vivo. In this study we used the potent, specific secretagogue impromidine which is an agonist with a high degree of specificity for the $\mathrm{H}_{2}$ receptor. It has no direct effect on muscarinic or gastrin receptors. Impromidine has between nine and 48 times the activity of histamine in vitro at the $\mathrm{H}_{2}$ receptor, ${ }^{8}$ and is up to 27 times more potent than histamine" in stimulating gastric acid secretion in vivo. In previous studies of human gastric acid secretion, an infusion of $10 \mu \mathrm{g} / \mathrm{kg} / \mathrm{h}$ achieved virtually maximal acid output. ${ }^{13}$

Interaction of histamine, or an $\mathrm{H}_{2}$ agonist, with the $\mathrm{H}_{2}$ receptor on the parietal cell results in activation of adenyl cyclase. The resultant increase in intracellular cyclic AMP results in activation of type I and II phosphokinases, with possible subsequent mobilisation of calcium ions from intracellular stores. ${ }^{14}$ Activation of the phosphokinase system results in alteration of the intracellular cytoskeleton with activation of the secretory canaliculus initiating hydrogen ion secretion by the proton pump. The end result is hydrogen ion secretion from the secretory canaliculus into the gastric lumen. ${ }^{14}$ In vitro studies have shown ${ }^{15}$ that incubation of human gastric cancer cell lines (HGT-1) with histamine results in desensitisation of the $\mathrm{H}_{2}$ receptor after only three hours. This phenomenon is known as 'down-regulation' of the receptor and for any given ligand receptor interaction, the resultant biological event will be reduced. Conversely, it might be expected that continued exposure of the $\mathrm{H}_{2}$ receptor to an antagonist might result in 'up-regulation' of the receptor. In previous studies, ${ }^{+6}$ the apparent increase in stimulated gastric acid secretion after continued $\mathrm{H}_{2}$ receptor antagonist treatment could have been attributed to a simple increase in parietal cell mass, to an increase in $\mathrm{H}_{2}$ receptor density, or to true biological 'up-regulation' of the $\mathrm{H}_{2}$ receptor. The present study suggests that the phenomenon of true 'up-regulation' has occurred after three months maintenance ranitidine treat- ment, as there is an increase in basal acid output, an exaggerated response to the secretagogue impromidine and most importantly, an accentuated response to intravenous ranitidine. Criteria for true 'up-regulation' are satisfied as for agonist and antagonist interactions with the receptor, the appropriate postreceptor event of stimulation or inhibition of acid secretion has been accentuated.

The final point for discussion concerns the potential that this 'up-regulation' might have for receptor interaction. In isolated parietal cells it has recently been shown that the $\mathrm{H}_{2}$ receptor and the prostaglandin receptor are closely linked. ${ }^{\text {th }}$ The $\mathrm{H}_{2}$ receptor acts through a guanine stimulatory nucleotide and the prostaglandin receptor acts through a guanine inhibitory nucleotide, each nucleotide being joined by a catalytic subunit which is linked to adenyl cyclase.

The clinical importance of 'up-regulation' of the $\mathrm{H}_{2}$ receptor remains unclear. Physiological stimulants of gastric acid secretion such as food, might be expected to cause an exaggerated secretory response. Conversely, a given dose of an $\mathrm{H}_{2}$ receptor antagonist might cause a more profound blockade during 'up-regulation'. Presumably, in clinical practice these two events would usually balance each other, suggesting that tachyphylaxis to $\mathrm{H}_{2}$ receptor antagonists is not likely to be a clinically significant problem. One possible clinical implication exists, however, because of the relationship between the $\mathrm{H}_{2}$ receptor and the prostaglandin receptor. ${ }^{17}$ If an increase in $\mathrm{H}_{2}$ receptor number persists for any length of time this could result in a reduced efficacy of prostaglandins given subsequent to treatment with an $\mathrm{H}_{2}$ receptor antagonist. Clearly further work is needed to clarify these mechanisms and their importance in clinical practice.

We are grateful to Smith, Kline \& French Research, Welwyn, Herts, UK for the gift of impromidine.

\section{References}

1 Black JW, Duncan WAM, Durant GJ, Ganellin CR, Parsons EM. Definition and antagonism of histamine $\mathrm{H}_{2}$-receptors. Nature 1972; 236: 385-90.

2 Meyrick-Thomas J, Misiewicz JJ. Histamine $\mathrm{H}_{2}-$ receptor antagonists in the short and long-term treatment of duodenal ulcer. Clin Gastroenterol 1984; 13: 501-41.

3 Misiewicz JJ, Bradbury JE. Review of maintenance treatment for the prevention of duodenal ulcer recurrence. In: Misiewicz JJ, Wood JR, eds. Ranitidine therapeutic advances. Amsterdam: Exerpta Medica, 1982: 42-71. 
4 Prichard PJ, Jones DB, Yeomans ND, Mihaly GW, Smallwood RA, Louis WJ. The effectiveness of rantidine in reducing gastric acid-secretion decreases with continued therapy. Br J Clin Pharmacol 1986; 22: 663-8.

5 Hyman PE, Abrams C, Garvey TQ. Ranitidine tachyphylaxis [Abstract]. Gastroenterology 1985; 88: 1426.

6 Sewing KF, Hagie L, Ippoliti AF, Isenberg JI, Samloff IM, Sturdevant RAL. Effect of one-month treatment with cimetidine on gastric secretion and serum gastrin and pepsinogen levels. Gastroenterology 1978; 74: $376-9$.

7 Code CF. Histamine receptors and gastric secretion. In: Ganellin CR, Parsons ME, eds. Pharmacology of histamine receptors. Bristol: Wright, 1982: 217-35.

8 Ganellin CR. Chemistry and structure-activity relationships of drugs acting at histamine receptors. In: Ganellin CR, Parsons ME, eds. Pharmacology of histamine receptors. Bristol: Wright, 1982: 10-102.

9 Durant GJ, Duncan WAM, Ganellin CR, Parsons EM, Blakemore RC, Rusmussen AG. Impromidine (SK \& F 92676 ) is a very potent and significant agonist for histamine $\mathrm{H}_{2}$-receptor. Nature 1978; 276: 403-5.

10 Snedecor GW, Cochran WG. Statistical methods. 7th ed. Ames, Iowa, USA: The Iowa State University Press, 1980.

1 i Grossman MI, Konturek SJ. Inhibition of acid secretion in dog by matiamide, a histamine antagonist acting on $\mathrm{H}_{2}$ receptors. Gastroenterology 1974; 66: 517-21.

12 Soll $\mathrm{AH}$. The interaction of histamine with gastrin and carbamylcholine and oxygen uptake by isolated mammalian parietal cells. J Clin Invest 1978; 61: 381-9.

13 Hunt RH, Mills JG, Beresford J, et al. Gastric secretory studies in humans with impromidine (SK \& F 92676) - a specific histamine $\mathrm{H}_{2}$-receptor agonist. Gastroenterology 1980; 78: 505-11

14 Jackson RJ, Berglindh $\mathrm{T}$, Malinowska $\mathrm{D}$, et al. Secretagogue stimulation of the gastric parietal cell. In: Uvnas B, Tasaka K, eds. Advances in histamine research. Oxford: Pergamon Press, 1982: 153-66.

15 Gespach $\mathrm{C}$, Emami $\mathrm{S}$. Histamine $\mathrm{H}_{2}$-receptors and gastric cells. In: Ganellin CR, Schwartz J-C, eds Frontiers in histamine research. Oxford: Pergamon Press, 1985: 265-74.

16 Soll AH. Mechanisms of action of antisecretory drugs. Studies on isolated canine fundic mucosal cells. Scand $J$ Gastroenterol 1986; [Suppl 125] 21: 1-6.

17 Hunt RH. Prostaglandins for peptic ulcer disease. Lancet 1987; i: 1262. 